Investigation of Symptoms and Hosts of Semi Parasite Plant Species in East Mediterranean and Central Anatolia Region of Turkey

Tamer ÜSTÜNER

KSÜ, Ziraat Fakültesi, Bitki Koruma Bölümü, Kahramanmaraş

$\square:$ tamerustuner@ksu.edu.tr

\title{
ABSTRACT
}

This study was carried out to determine the symptoms and hosts of the semi parasitic plant species causing problems on the forest and fruit trees in the East Mediterranean (Kahramanmaras) and Central Anatolia region (Nigde) in 2012-2016. When these semi parasitic plants appear on the plants, they can cause swelling at the germinated sites of branches of their host and resulting backward tissue drying. It has also been observed to cause the host to die completely in some host such as almonds and apricot. The study was conducted in Nigde, through the Mistletoe survey performed on some fruit and park trees and the results indicated that a subspecies of semi parasitic. Viscum album naming Viscum album ssp. album was living on these trees. The whitethorn, wild pear, Ankara pear, almond, Braeburn apple, plum, apricot, sour cherry, locust, Canada poplar and willow were found to be the host for Viscum album ssp. album. Other mistletoe species; Viscum album ssp. abietis was seen on Taurus fir and Taurus cedar while Viscum album subsp. austriacum on Pinus nigra subsp. pallasiana.

In Kahramanmaras, Dwarf mistletoe (Arceuthobium oxycedri) was seen on Small fruited pine (Juniperus oxycedrus subsp. oxycedrus), Crimean juniper (Juniperus excelsa Bieb.) and Syrian juniper (Juniperus drupacea Labill.); Yellow mistletoe (Loranthus europaeus) was seen on Turkey oak (Quercus cerris) and Aleppo oak (Quercus infectoria); White mistletoe (Viscum album subsp. abietis) on Taurus fir (Abies cilicia subsp. cilicica) and Taurus cedar (Cedrus libani); Pine mistletoe ( $V$. album subsp. austriacum) was seen on Pinus nigra (Pinus nigra subsp. pallasiana). On the other hand, Viscum album ssp. album was not found on any host in Kahramanmaras.

\section{Türkiye'nin Doğu Akdeniz ve İç Anadolu Bölgeler'inde Görülen Yarı Parazit Bitki Türlerin Konakları ve Simptomlarının Araştırılması}

\section{ÖZET}

Bu çalışma 2012-2016 yıllarında Niğde ve Kahramanmaraş illerinde meyve ve orman ağaçlarında sorun olan yarı parazit bitki türlerinin, konukçuları ve simptomlarını belirlemek için yapılmıştır. Bu yarı parazit bitkiler konukçuların dallarında çimlendiği yerde şişkinliklere neden olduğu gibi sürgün uçlarından geriye doğru kurumalara da neden olmaktadır. Ayrıca kayısı ve badem gibi bazı konukçularda ağaçların tamamen kurumasına neden olduğu gözlenmiştir. Niğde ilinde; meyve ve park ağacı türlerinde yapılan ökseotu sürveyi neticesinde bu ağaçlarda yarı parazit yaşayan Viscum album türüne ait alt türün Viscum album ssp. album olduğu belirlenmiştir. Alıç, ahlat, Ankara armudu, badem, elma, erik, kayısı, vişne, akasya, kanada kavağı ve söğüt ağaçlarında Viscum album ssp. album'a rastlanmıştır. Diğer ökse otu türleri, Viscum album ssp. abietis Toros göknarı ve Toros sedirinde, Viscum album subsp. austriacum ise karaçamda görülmüştür.
DOI:10.18016/ ksudobil.350489

\section{Article History}

Received : 10.11.2017

Accepted : 12.12.2017

\section{Keywords}

Arceuthobium

loranthus,

viscum, symptom, fruit and pine trees

\section{Research Article}

MakaleTarihçesi

GelişTarihi : 10.11.2017

Kabul tarihi : 12.12.2017

AnahtarKelimeler
Arceuthobium,
oranthus,
viscum,
simptom,
meyveveçamağaçları

AraştırmaMakalesi 
Kahramanmaraş ilinde; Ardıç ökseotu (Arceuthobium oxycedri); küçük kozalaklı katran ardıç (Juniperus oxycedrus subsp. oxycedrus), boylu ardiç (Juniperus excelsa) ve andizda (Juniperus drupacea), meşe ökseotu (Loranthus europaeus) saçlı meşe (Quercus cerris) ve mazı meşesinde ( $Q$. infectoria), Göknar ökseotu (Viscum album subsp. abietis) Toros göknarı (Abies cilicica subsp. cilicica) ve Toros sedirinde (Cedrus libani) ayrıca çam ökseotu ( $V$. album subsp. austriacum) kara çamda (Pinus nigra subsp. pallasiana) görülmüş diğer yandan Kahramanmaraş'ta Viscum album ssp. album'a hiç bir konukçuda rastlanmamıştır.

To Cite : Üstüner T 2018. Türkiye’nin Doğu Akdeniz ve İç Anadolu Bölgeler'inde Görülen Yarı Parazit Bitki Türlerin Konakları ve Simptomlarının Araştırılması KSÜ Tarim ve Doğa Derg 21(3).438-446. DOI:10.18016/ ksudobil.350489

\section{INTRODUCTION}

Conifer trees and fruit production are among the important agro-forestry activities in Turkey. Many external factors and pests affect yield and quality of the timber production, and parasitic and semi-parasitic plants are the foremost pests among them. Miller (1982) showed that the term mistletoe was first applied to the European mistletoe (Viscum album). Viscum species include three subspecies belonging to the species of Viscum album in Turkey. These subspecies are Viscum album ssp. album, Viscum album ssp. abietis and Viscum album ssp. austriacum. Ball (1993) showed that three widely distributed subspecies of $V$. album that differ in host specificity have been recognised in Europe: $V$. album subsp. album on dicotyledonous trees, $V$. album subsp. abietis on Abies spp. and $V$. album subsp. austriacum on Pinus spp. and rarely Larix spp.

Mistletoe species can perform photosynthesis because of having chlorophyll. However they do not possess a root system like the other plants. Haustorium of mistletoe penetrates to xylem of host to take minerals and water. Mistletoe species have flowers and seedsand the external surfaces of the seeds are sticky, so they can easily stick on tree branches and can germinate on hosts (Hawksworth and Scharpf, 1986; Hawskworth and Wiens, 1996). Loranthusis a genus of parasitic plants that grow on the branches of woody trees. Modern systematists consider it as a monotypic genus with the only species Loranthus europaeus Jacq. the summer mistletoe or European yellow mistletoe. According to Hegi (1981) Loranthus europaeus Jacq. exists on oaks, mostly on downy oak (Quercus pubescens Willd.), Turkey oak (Quercus cerris L.), pedunculate oak (Quercus robur L.) and sessile oak (Quercus petraea (Matt.) Liebl.). Arceuthobium oxycedri was reported in Balkan states of Slovenia, Croatia, Bosnia Herzegovina, Yugoslavia and Pakistan on Juniperus communis, J. drupacea and J. oxycedrus (Bondev and Lybenova, 1984; Khaldi et al., 2000; Sarangzai et al., 2010). Species of the genera Psittacanthus, Phoradendron, and Arceuthobium have the greatest economic and ecological impacts in the Western United States and in Mexico (Geils et al., 2002a-2002b). Viscum species spread in many regions of Europe, North Africa, Austria, Asia, China, Western Europe, southern England, Scandinavia, the Balkans, Russia, Japan and Nigeria (Frohne and Pfander, 1984; Kirkup et al., 2000; Ciesla et al., 2004). The study in Kahramanmaras showed that the ratio of existence of $A$. oxycedri on the host were determined as high dense 16.99 number/host for J. oxycedrus subsp.oxycedrus, 15.33 for J. excelsa and 14.38 for J. drupacea. Also $L$. europaeus was found dense 3.32 on $Q$. cerris and 2.74 on $Q$. infectoria. Another semi-parasite plant, $V$. album subsp. abietis was determined as dense 9.92 on $A$. cilicica subsp. cilicica, while it was mid dense 0.44 on C. libani. Besdies, V. album subsp. austriacum was found as high dense 14.53 number/host on $P$. nigra subsp. pallasiana (Üstüner, 2016).

To our knowledge, so far, there was no any studies related symptoms of semi parasitic plants conducted in Kahramanmaras and Nigde.

\section{MATERIALS and METHODS}

\section{Materials}

The material of this research is mistletoe species, fruit and forest trees. Surveys were conducted in East Mediterranean (Kahramanmaras province) and Central Anatolia region (Nigde province) in 20122016.

\section{Methods}

Mistletoe branches were counted to using field glass for tall trees. Special coverage was calculated via formula proposed by Odum (1971), where SC= Total \% coverage of each species/measuring the count of each species found

Infection severity of the semi parasites was calculated with formula proposed by Üstüner et al. (2015) with the following equations;

Infection severity $(\%)=\left(a{ }^{*} \mathrm{Co}\right)+(b *$ Dried Branches Rate $)+\left(c^{*}\right.$ T.A $)+\left(d^{*}\right.$ S.R. $)$ 
where $\mathrm{Co}=$ Coverage, $\mathrm{a}=1$. Coefficient value, D.B.R.= Dried branches rate, $b=2$. Coefficient value, $T A=$ Tree age. $c=3$. Coefficient value, Swelling rate= S.R. $d=4$. Coefficient value.

The presentation of infection severity scales were given in Table 1.

Table 1. Scale of infection severity of mistletoe species on hosts

\begin{tabular}{ccc} 
Scale value & Infection rate & Scale of infection \\
\hline 1 & $0-10$ & Less severe \\
\hline 2 & $10-40$ & Moderate to severe \\
\hline 3 & $40-70$ & Severe \\
\hline 4 & $70-100$ & Very severe \\
\hline
\end{tabular}

\section{RESULTS}

Symptoms and hosts of Viscum, Arceuthobium and Loranthus species were investigated in East Mediterranean (Kahramanmaras province) and Central Anatolia region (Nigde province).

$V$. album ssp. album in shrub shape and $19-28 \mathrm{~cm}$ tall, the leaves are dark green, opposite pairs, strapshaped, entire, leathery textured, $3-5 \mathrm{~cm}$ long and 1-1.5 $\mathrm{cm}$ broad, fruits are round and white colour (Figure1). The stems length are13-38 cm with dichotomous branches.

Based onthe survey in Nigde, $V$. album ssp. album was seen on the fruit trees including almond (Amygdalus spp.), Ankara pear (Pyrus communis L.), Apricot (Prunus armenica L.), Braeburn apple (Malus domestica cv Braeburn), Plum (Prunus spp.), Sour cherry (Prunus cerasus L.), Whitethorn (Crataegus monogyna Jacq) and Wild pear (Pyrus elaeagnifoila Pallas), while also it was seen on the park trees; Locust
(Robinia spp.), Canada poplar (Populus canadensis Michx) and Willow (Salix spp.). Whereas, V. album ssp. album was not seen on any host in Kahramanmaras.

The infection rates by $V$. album ssp. album was high on Almond (Amygdalus spp.) 50.5\%, Apricot (Prunus armenica L.) $36.90 \%$, Pear (Pyrus communis L.) 29.66\% and were low on plum (Prunus spp.) $3.60 \%$ and on apple (Malus domestica cv Braeburn) 3.20\%. After germinating and penetrating its hostourium to host xylems, mistletoe results sweelling in the germination site. As result of this infection, almond and apricot shoot tips died, and after 3 to 4 years some trees were completely dead (Figure 2). But smilar symptoms were not seen on locust (Robinia spp.), Canada poplar ( $P$. canadensis Michx) and willow (Salix spp.).

$V$. album ssp. abietis similar to $V$. album ssp. album but there were some diffreneces like leaves size $2 \mathrm{x} 0.8$ $\mathrm{cm}$ and stem length 9-30 $\mathrm{cm}$ (Figure 3). Also the leaves were yellowish-green and fruit eliptic.

The infection severity of $V$. album subsp. abietis on $A$. cilicica subsp. cilicica was determined as moderate to severe with the ratio of $15.80 \%$, while it was less severe on Cedrus libani with the ratio of $4.80 \%$ in Nigde. Simultaneously, the infection severity on $A$. cilicica subsp. cilicica was moderate to severe with the ratio of $10.73 \%$, and was less severe on $C$. libani with the ratio of $3.40 \%$ in Kahramanmaras. Two symptom case of $V$. album subsp. abietis infections were observed. One of which was at needle leafed. A. cilicica subsp. cilicica where shoot tips were dried (Figure 4), while the other case was on $C$. libani where no dryness were occured. However, the swelling at branches of both mistlete hosts were observed during the infection (Figure 5, 6 and 7).
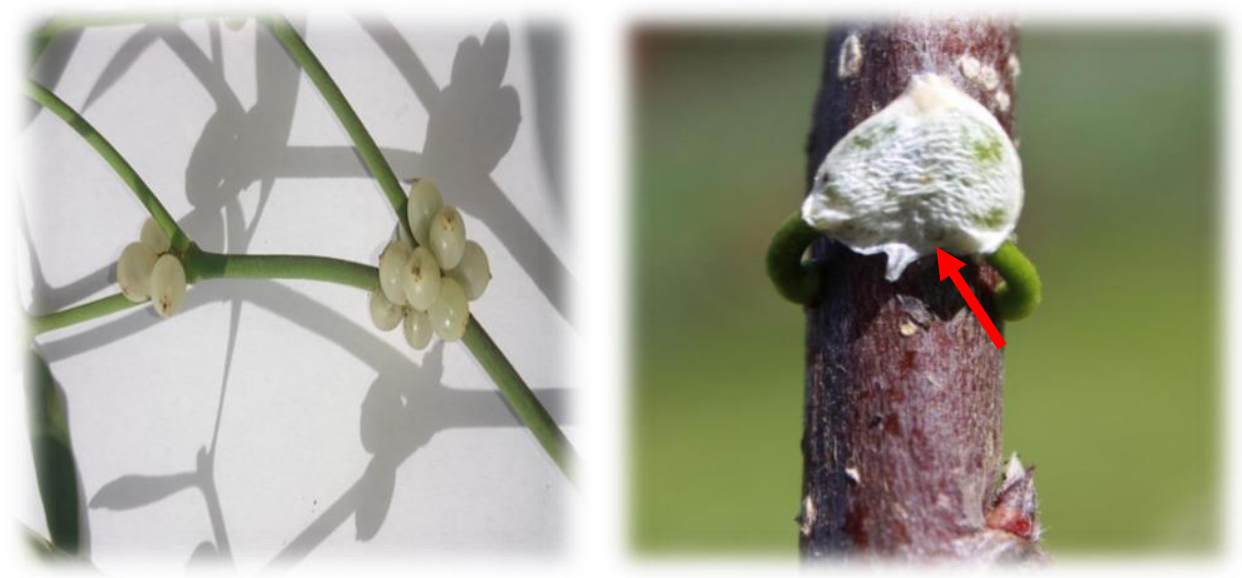

Figure 1. White fruit of V. album ssp. album (Üstüner et al., 2015) and seed germination (Heide-Jørgensen, 2015) 

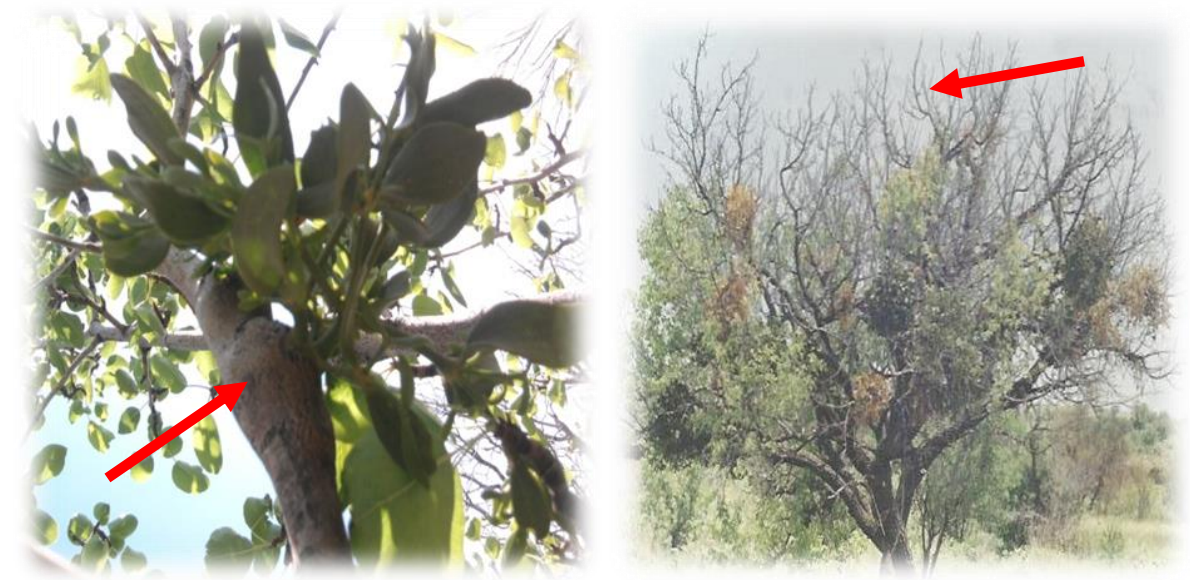

Figure 2. $V$. album ssp. album caused to swelling at the germination site on the branches of the pear (left) and to dry and die back of the shoot tips of apricot (right) (Üstüner at al., 2015).
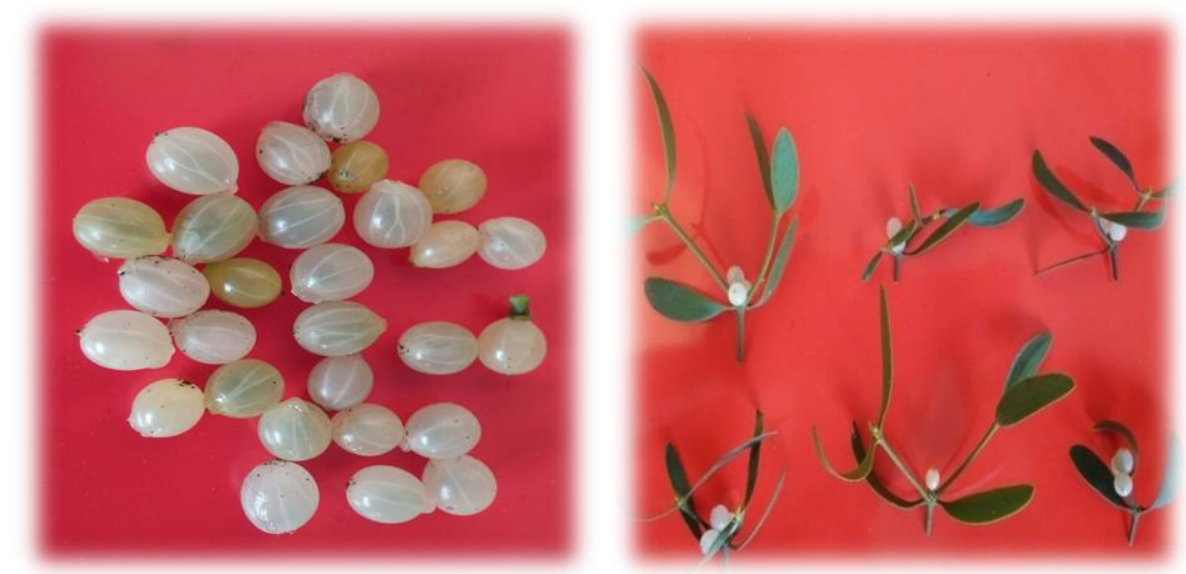

Figure 3. White fruits of $V$. album subsp. abietis and dichotomous branching (Üstüner at al., 2015)

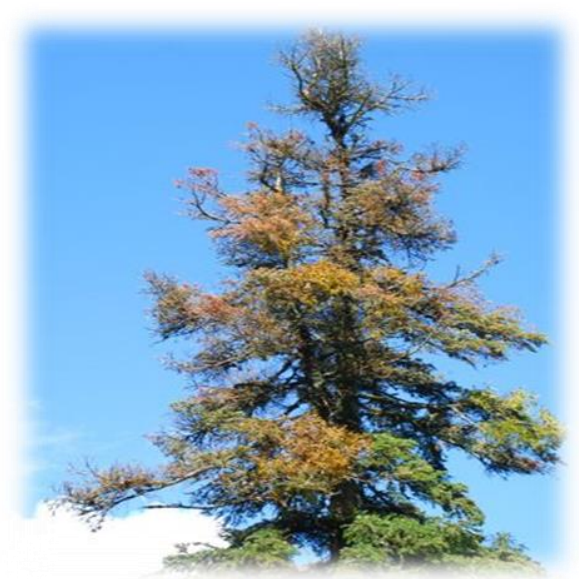

Figure 4. Symptoms of $V$. album subsp. abietis on pine needles of A. cilicica subsp. cilicica 

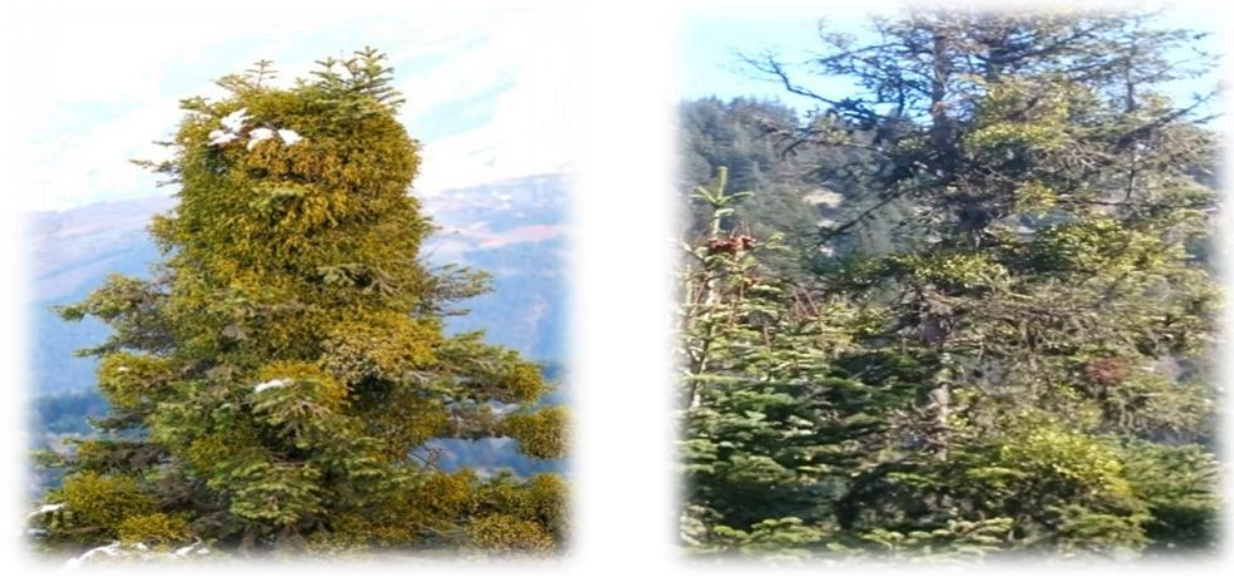

Figure 5. V. album subsp. abietis dried shoot tips of $A$. cilicica subsp. cilicica
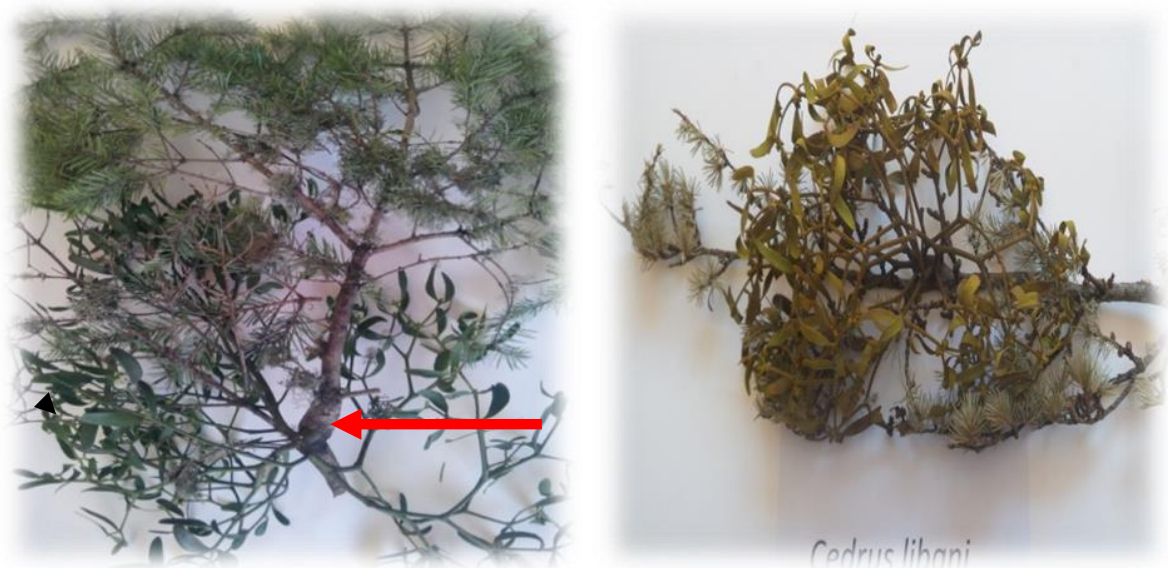

Figure 6. V. album subsp. abietis germination sites on C. libani branch.
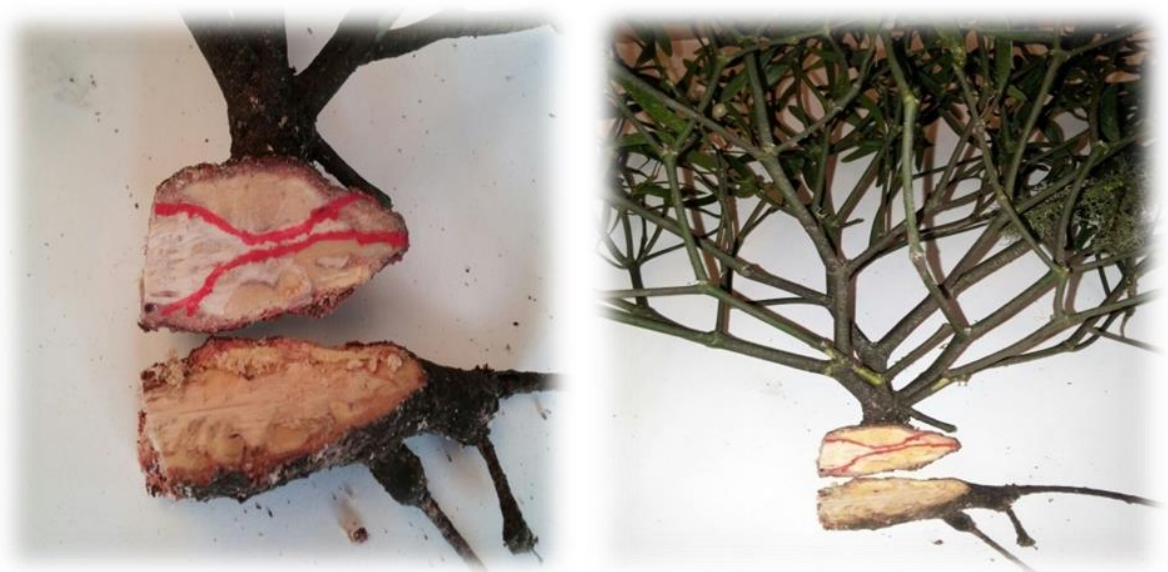

Figure7. V. album subsp. abietis is causing clogging of xylem, resulting swelling left, drying and dying back of the shoot tips of pine needles (Üstüner at al., 2015).

$V$. album ssp. austriacum is similar to $V$. album ssp. album and $V$. album ssp. abietis but there are some diffreneces like leave size $2.80 \times 0.70 \mathrm{~cm}$ and stem length $15-28 \mathrm{~cm}$ (Figure 8). Also the leaves are slightly yellowish-green. The ratio of infection severity of $V$. album subsp. austriacum was $10.24 \%$ on $P$. nigra subsp. pallasiana in Nigde and was $16.23 \%$ in Kahramanmaras. The symptoms of $V$. album subsp. austriacum resulted swelling at the germination site at branches, and needle leaf driyness. Pine trees infected by mistletoe have a tendency to live longer. 

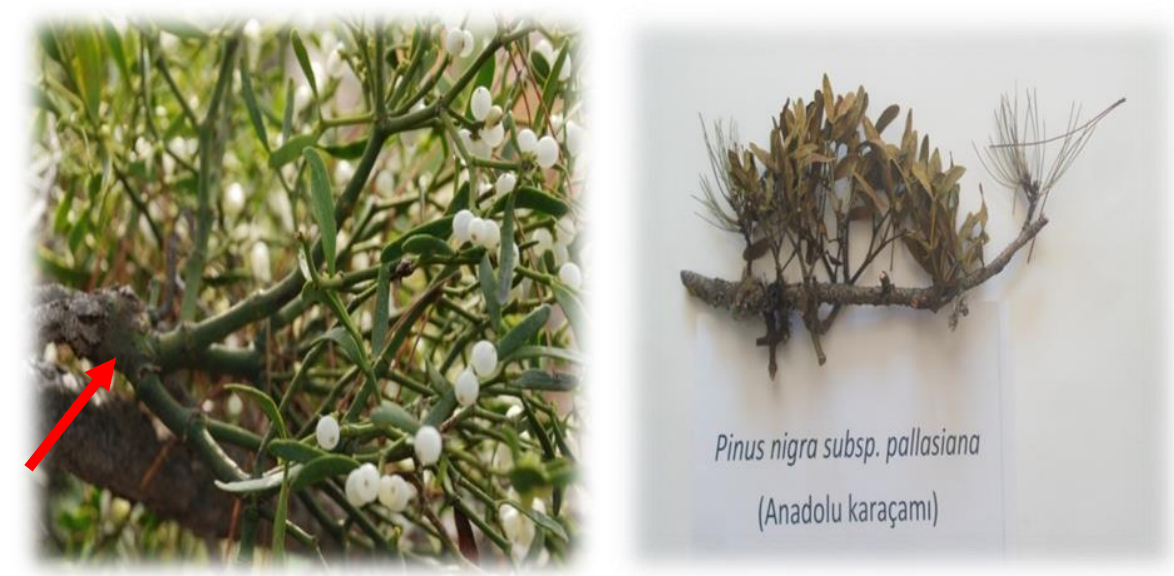

Figure 8. V. album subsp. austriacumcause swelling on the branche.

Shoots of Dwarf mistletoes (A. oxycedri) are mostly 5$10 \mathrm{~cm}$ tall, deep green and verticillate branching. The mature fruit is elips and $3.0 \times 1.5-2.0 \mathrm{~mm}$ in size. $A$. oxycedri was not seen in Nigde. While in Kahramanmaras the infection severity of $A$. oxycedri was determined as moderate to severe with a ratio of
$10.82 \%$ for $J$. oxycedrus subsp. oxycedrus, as less severe with that ratio of $8.57 \%$ for $J$. excelsa and as $7.78 \%$ for J. drupacea. Symptoms followed at first on needle leaf then on shoot tips causing them to dry on the hosts (Figure 9 and 10), and causing shoots completely to dry at the end.

Figure 9. A. oxycedri on J.oxycedrus subsp. oxycedrus.
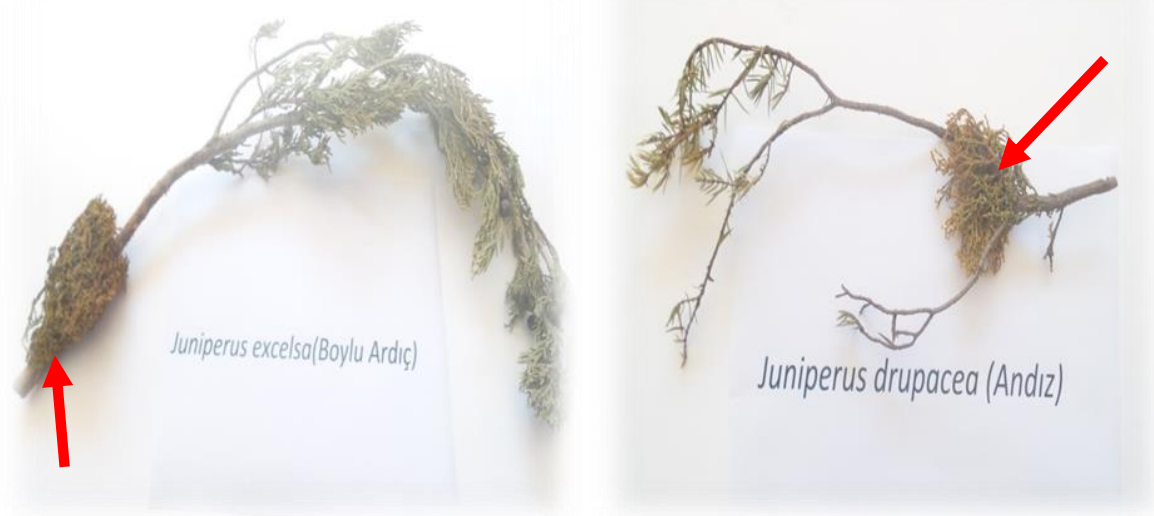

Figure 10. A. oxycedri on J. excelsa and J. drupacea 
L. europaeus possess a similar branching pattern to the evergreen mistletoe Viscum album, but it is deciduous, yellow-berried mistletoe with dull brown twigs. L. europaeus was not seen in Nigde, but it was seen on two host in Kahramanmaras. Infection severity of $L$. europaeus was less severe and was $8.69 \%, 7.97 \%$ for $Q$. cerris and $Q$. infectoria, respectively. Symptoms occurred resulting shoot tips and leaves of hosts to dry. In addition, L. europaeus caused swelling in the branches (Figure 11) resulting Oak shoots to dry completely (Figure 12).
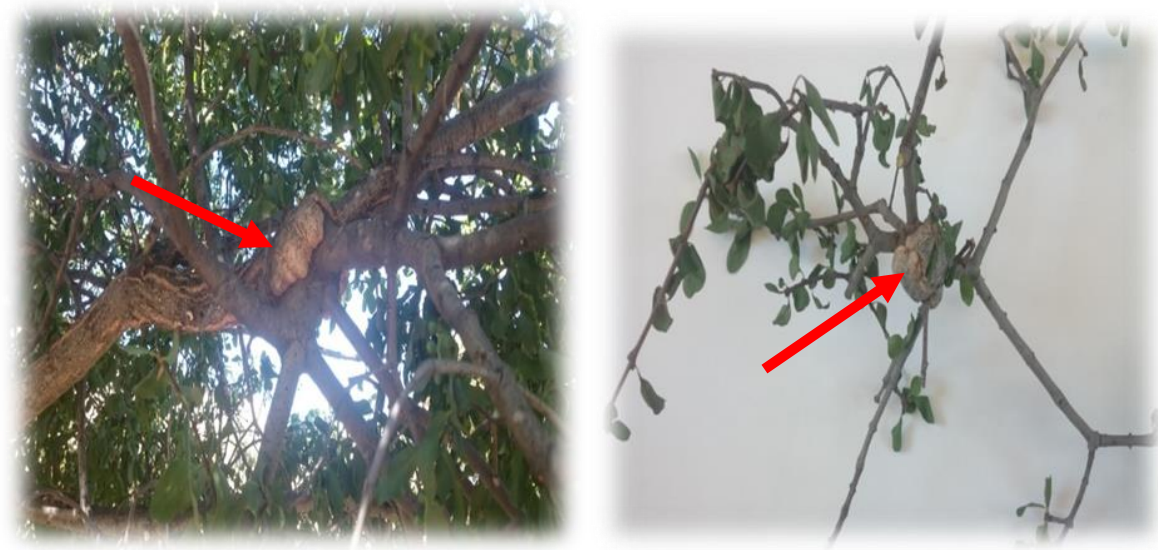

Figure 11. Loranthus europaeus caused swelling on branches.
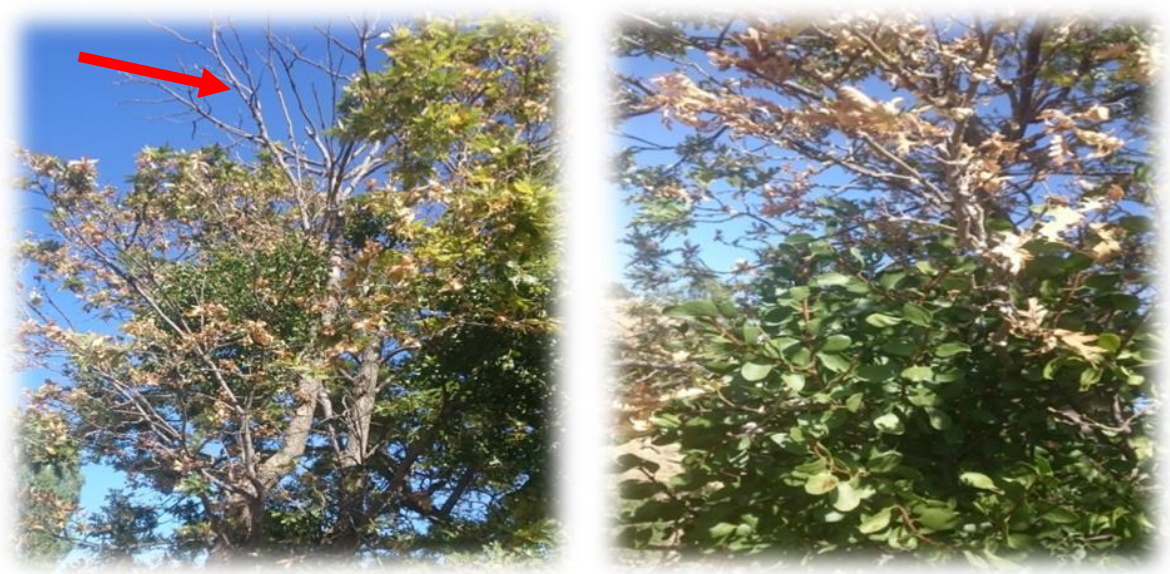

Figure 12. L. europaeus dried shoot tips of Quercus cerris and $Q$. infectoria.

$V$. album ssp. album was observed on 11 hosts in Center of Nigde, 10 hosts in Bor, 9 hosts in Ulukısla, 7 hosts in Altunhisar and 5 hosts in Ciftlik district and none in Camardı. V. album subsp. abietis and V. album subsp. austriacum were seen on 2 hosts in Center Nigde, Ulukısla and Camardı, 1 host in Bor district of Nigde. V. album subsp. abietis was seen on 1 host in Center, Afsin and Ekinozü, 2 in Andırın and Göksunnone in Caglayancerit, Elbistan, Nurhak, Pazarcık and Türkoglu. V. album subsp. austriacum was seen on 1 host in Center, Afsin, Andırın, Caglayancerit, Göksun, Pazarcık, Türkoglu and Ekinozü while it was not seen in Elbistan and Nurhak district of Kahramanmaras. A. oxycedri was not seen on hosts in Nigde, while it was seen on 3 hosts in Center, Afsin, Andırın, Caglayancerit, Ekinozü, Elbistan, Göksun, Nurhak; yet, it was not seen in Pazarcık and Türkoglu district of Kahramanmaras. $L$. europaeus was not found in Nigde but it was foundon
2 hosts in Afsin, Andırın, Caglayancerit, Ekinozü, Elbistan, Göksun and Nurhak.

\section{DISCUSSION}

Infection severity of mistletoe species were determined according to hosts in Nigde and Kahramanmaras. $V$. album subsp. album was found in different rate (3.2$50.50 \%$ ) on host of Nigde but it was not seen in Kahramanmaras. V. album subsp. abietis was detected different rate (3.40-15.80\%) on hosts; $V$. album subsp. austriacum was detected at different rate (10.24$16.23 \%$ ) on hosts. A. oxycedri was not seen in Nigde. The ratio of infection severity of $A$. oxycedri on the host were determined between $7.78-0.82 \%$ in Kahramanmaras. L. europaeus was not seen in Nigde but infection severity of $L$. europaeus was found less severe between $7.97-8.69 \%$ on hosts of Kahramanmaras. 
The rate of infection by $V$. album ssp. album was high on Almond 48.54\%, Apricot $34.98 \%$ and on Pear $28.64 \%$. The ratio of infection severity of $V$. album subsp. abietis was moderate to severe with the ratio of $2.40-9.73 \%$ on hosts. Similarly, $V$. album subsp. austriacum was found moderate to severe with a ratio of $15.25 \%$ on $P$. nigra subsp. pallasiana. Another semi parasite plant, the ratio of infection severity of $A$. oxycedri on the host were detected moderate to severe with a ratio of $7.78-10.82 \%$ for related hosts. Also infection severity of $L$. europaeus was found less severe as 7.97-8.69\% on hosts (Üstüner et al., 2015; Üstüner 2016). A. oxycedri is widespread in Turkey, A. oxycedri was usually found on $J$. oxycedri and J. drupacea trees in Turkey (Miller, 1982; Hawksworth and Wiens, 1996).

Arceuthobium species were detectedat various rates of 10-20\% on Juniperus species (Lazarev and Grigorov, 1980), 3-32\% on pinus (Hawksworth and Johnson, 1989), $42 \%$ on Douglas-fir (Bolsinger, 1978) and 57\% on conifer (Marsden et al., 1991). V. album ssp. austriacum has killed $15-20 \%$ of Pinus sylvestris branches (Dobberting and Rigling, 2006). The infection severity of mistletoe was 14\% in Spain (Oliva and Colinas, 2007), 30\% in Croatia (Idžojtić et al., 2008) and $22 \%$ in Romania (Barbu, 2009). V. album ssp. abietis infected Silver fir at a $20-40 \%$ rate (Barbu, 2012). The infection rate of $V$. album ssp. album on oak was $12.9 \%$ (Matula et al., 2015). Infection severity of Mistletoe species may varies according to different host, density, region, ecology and growing conditions. The results of previous studies were partially similar with these results.

After mistletoe germination hostourium penetrated to host xylems, the sweelling was formed at germination site. Mistletoe infections lower the vigor of the host, induce premature mortality, reduce the quality and quantity of wood produced. Heavily infected trees die following a few years (Bhattacharyya and Uniyal, 1982; Hawksworth, 1983). Most infected trees with $A$. oxycedri can survive for several decades; generally the smaller trees decline and die more quickly than the larger ones. The first symptom of dwarf mistletoe infection is a slight swelling of the bark at the infection site (Hawksworth and Geils, 1990; Hawksworth and Wiens, 1996; Koski et al., 2013). L. europaeus has a similar branching pattern to the evergreen mistletoe Viscum album L., infected trees with L. europaeus may be reduced in vigor, stunted, or even killed. On some host species large swelling occure at the infected branches where the mistletoe penetration taken place (Perry et al., 2006; Zebec and Idsotij, 2006).

Different symptoms and hosts range of mistletoe species were determined in Nigde and Kahramanmaras. Similar results reported by Miller (1982), Hawksworth and Wiens (1996), Üstüner et al. (2015) and Üstüner (2016) in Turkey. Simultaneously
Hawksworth and Johnson (1989), Dobberting and Rigling (2006), Oliva and Colinas (2007), Idžojtić et al. (2008) and Barbu (2012), Matula et al. (2015) reported partially similar results with the current study in the world.

\section{CONCLUSION}

Infection severity of mistletoe species may be differ according to hosts, density, region and ecosystem in Nigde and Kahramanmaras.

Mistletoe species caused swelling at the germinated site in the branches of the host and caused the shoot tips of host to dry. $V$. album subsp. abietis caused $A$. cilicica subsp. cilicica needles leaves to dry first, then the shoot and finaly kill the host completely. Pine trees infected by Viscum can live longer but apricots and almonds could not. Swellings on the branches and shoot tips of $Q$. cerris and $Q$. infectoria were killed by L. europaeus.

\section{ACKNOWLEDGEMENTS}

My appreciations go to Prof.Dr. Sibel Uygur for making diagnosis of mistletoe species, from Cukurova University, Agriculture Faculty, department of Plant Protection. I also thank to the Regional Directorate of Forestry of Kahramanmaras for their help in this study.

\section{REFERENCES}

Ball PW 1993. Viscum L. In flora Europaea. p. 86. Cambridge Univ. Press, Cambridge, UK.

Barbu C 2009. Impact of Mistletoe Attack (Viscum album ssp. abietis) on Radial Growth of Silver fir. A case study in the North of Eastern Carpathians. Annals of Forest Research, 52: 89-96.

Barbu C 2012. Impact of White Mistletoe (Viscum album ssp. abietis) Infection on Needles and Crown Morphology of Silver Fir (Abies alba Mill.). Not. Bot.Horti Agrobo, 2012, 40(2): 152-158. Print ISSN 0255-965X; Electronic, 1842-4309.

Bhattacharyya UC, Uniyal BP 1982. A Botanical Tourto Pangi and Triloknath in the upper Chenab. J Bombay Natural History Society, 79: 57-78.

Bolsinger CL 1978. The Extent of Dwarf Mistletoe in Six Principal Soft woods in California, Oregon, and Washington, as Determined From Forest Survey Records. In Proceedings of the Symposium on Dwarf Mistletoe Control through Forest Management, 11-13 April.

Bondev IA, Lyubenova MI 1984. Materials and Critical Notes on the Bulgarian Flora.Fitologija, 24:64-67.

Ciesla WM, Geils BW, Adams RP 2004. Hosts and Geographic Distribution of Arceuthobium oxycedri. United States Department of agriculture forest service, US. 
Dobbertin M, Rigling A 2006. Pine mistletoe (Viscum album ssp. austriacum) Contributes to Scots Pine (Pinus sylvestris) Mortality in the Rhone Valley of Switzerland. For. Path., 36: 309-322.

Frohne D, Pfander HJ 1984. Mistletoe. In a Colour Atlas of Poisonous Plants. 1st ed. Wolfe Pub., pp: 155-156, London, UK.

Geils BW, Wiens D, Hawksworth FG 2002a. Phoradendron in Mexico and the United States. USDA Forest Service Gen Tech. Rep.

Geils BW, Tovar JC, Moody B 2002b. Mistletoes of North AmericanConifers. Gen. Tech. Rep. RMRSGTR-98. Ogden, UT: U.S. Department of Agriculture, Forest Service, Rocky Mountain Research Station. 123 p.

Hawksworth FG 1983. Mistletoes as Forest Parasites. In: The biology of mistletoes (eds. Calder M, Bernhardt P), pp. 317-333. Academic Press Australia.

Hawksworth FG, Scharpf RF 1986. Spread of European Mistletoe (Viscum album L.) in California, US. European J. Forest Pathology,16:15.

Hawksworth FG, Johnson DW 1989. Biology and Management of Dwarf Mistletoe in Lodgepole Pine in The Rocky Mountains, USDA Forest Service Rocky Mountain Forest and Range Experiment Station, General Technical Report Rm-169, Colorado, $38 \mathrm{p}$.

Hawksworth FG, Geils BW 1990. How Long Do Mistletoe-Infected Ponderosa Pines Live? West. J. of App. Forestry, 5(2):47-48.

Hawksworth FG, Wiens D 1996. Dwarf Mistletoes: Biology, Pathology and Systematics. Agric. Handb. 709. Washington DC: US Department of agriculture. 410 pp. [online] Available: http://www.rms.nau.edu/publications/ah 709 .

Hegi G 1981. Illustrierte Flora von Mittel europa, Band III, Teil 1. Verlag Paul Parey, Berlin, Hamburg, 504 pp.

Heide-jørgensen HS 2015. The Mistletoe Viscum album. www.viscum. dk

Idžojtić M, Pernar RM, Glavaš M, Zebec M,Diminić D 2008. TheIncidence of Mistletoe (Viscum album ssp. abietis) on Silver Fir (Abies alba) in Croația. Biologia, 63(1):81-85.

Khaldi A, Khouja ML, Abdelmoula K, Khouaja A 2000. The Situation of Juniperus phoenicea and Juniperus oxycedrus in Tunisia. Paper presented at the international Symposium Problems of Juniper Forests, Osh, Kyrgyzstan.
Kirkup DW, Polhill RM, Wiens D 2000. Viscum in the Context of its Family Viscaceae and Its Diversity in Africa. In: Mistletoe: The Genus Viscum, ed. A. Bussing. Harwood Academic Publishers.

Koski RD, Jacobi, WR, Swift, CE 2013. Mistletoes in Colorado Conifers. Colorado State University Extension. 2/99. Revised 12/13.

Lazarev MA,Grigorov AN 1980. Modern Conditions and Perspectives of Studying Arceuthobium M.B. parasitizing the Crimean junipers. Byull. Gos. Nikit. Bot. Sada., 1:64-67.

Marsden MA, Filip GM, Hessburg PF 1991. Using the Forest Timber Inventory for Sampling The Occurrence of Pests on Interior Douglas-fir. In: Baumgartner, D.M.; J.E. Lotan, comp. and eds.; Symposium proceedings: Interior Douglas-fir, the species and its management. February 27-March 1, 1990. Cooperative Extension, Washington State University, Pullman, WA. p. 109-113.

Matula R, Svátek M, Pálková M, Volařík D,Vrška T 2015. MistletoeInfection in an Oak Forest is Influenced by Competition and Host Size Radim. PLoS ONE, 10(5): e0127055. doi:10.1371/journal.pone.0127055

Miller AG 1982. Arceuthobium Bieb. and Viscum album L. (Flora of Turkey and the East Aegean Islands), University Press, Edinburgh.

Odum EP 1971. Fundamantals of Ecology. W.B: Saunders company, Philedelphia, London, Toronto, p.547.

Oliva J, Colinas C2007. Decline of Silver fir (Abies alba Mill.) Stands in the Spanish Pyrenees: Role of Management, Historic Dynamics and Pathogens. Forest Ecol. Manag, 252:84-97.

Perry J, Elmore CL, Emeritus D 2006. Mistletoe. University of California Agriculture and Natural Resources, Pest Notes, Publication,7437, Page;1-3.

Sarangzai AM, Khan N, Wahab M, Kakar A 2010. New Spread of Dwarf Mistletoe (Arceuthobium oxycedri) in Juniper Forests, Ziarat, Balochistan, Pakistan. Pakistan J. Bot., 42(6): 3709-3714.

Üstüner T, Düzenli S,Kitis YE 2015. Determination of Infection Rate of Mistletoe ( $V$. album) On Hosts in Nigde Province. J. Turkish Weed Sci.,18(1-2); 5-14.

Üstüner T 2016. Infection Severity of Semi Parasite Species on Hosts in East Mediterranean Region of Turkey. IOSR Journal of Agriculture and Veterinary Science (IOSR-JAVS),9(11):17-25.

Zebec M, Idžojtić M 2006. Hosts and Distribution of Yellow Mistletoe, Loranthus europaeus Jacq. In Croatia. Ladnikia, 19: 41-46. 